\title{
PATTERNS OF SEED DISPERSAL SYNDROMES AT DIFFERENT ALTITUDES IN THE SEMIARID REGION
}

\author{
Wedson Batista dos Santos ${ }^{1 *}$, Luiz Carlos Marangon ${ }^{2}$, Fernando José Freire ${ }^{3}$, Rafael Leite Braz ${ }^{4}$, José Edson de \\ Lima Torres ${ }^{5}$, Clarissa Soares Freire ${ }^{6}$ \\ 1*Universidade Federal Rural de Pernambuco, Departamento de Ciência Florestal, Recife, Pernambuco, Brasil - wedsonsantosfl@gmail.com
${ }^{2}$ Universidade Federal Rural de Pernambuco, Departamento de Ciência Florestal, Recife, Pernambuco, Brasil - lcmarang@ @erra.com.br
${ }^{3}$ Universidade Federal Rural de Pernambuco, Departamento de Agronomia, Recife, Pernambuco, Brasil - fernandojfreire@ @ol.com.br
${ }^{4}$ Universidade Federal Rural de Pernambuco, Departamento de Ciência Florestal, Recife, Pernambuco, Brasil - rlbraz.ufrpe@ @mail.com
${ }^{5}$ Universidade Federal Rural de Pernambuco, Departamento de Ciência Florestal, Recife, Pernambuco, Brasil -
edsonfloresta@ yahoo.com.br
${ }^{6}$ Universidade Federal Rural de Pernambuco, Departamento de Ciência Florestal, Recife, Pernambuco, Brasil - clarissa.sfreire@ gmail.com
}

Received for publication: 07/02/2019 - Accepted for publication: 03/09/2019

\begin{abstract}
Resumo
Padrões de síndromes de dispersão de diásporos sob diferentes altitudes em região semiárida. O objetivo deste estudo foi avaliar os padrões de síndromes de dispersão de sementes da vegetação lenhosa, de nove fragmentos florestais distribuídos em diferentes níveis de altitudes na serra do Araripe, Pernambuco, Brasil. Para a coleta de dados, a região foi estratificada em três níveis de altitudes: inferior (altitudes $\leq 600 \mathrm{~m}$ ), intermediário $(600<$ altitudes $<750 \mathrm{~m})$ e superior (altitudes $\geq 750 \mathrm{~m}$ ). Foram inventariados nove fragmentos, sendo três por estrato de altitude. Em cada fragmento foram distribuídas 20 unidades amostrais retangulares com $250 \mathrm{~m}^{2}$, totalizando uma área amostral de 4,5 ha. Foram quantificados, coletados e identificados os indivíduos lenhosos com nível de inclusão de circunferências a altura do peito maior ou igual a 0,10 m (CAP $1,30 \mathrm{~m} \geq 0,10 \mathrm{~m}$ ). A caracterização da síndrome de dispersão foi realizada segundo as características dos frutos e sementes, e com base em revisão de literatura. Em toda região foram amostrados 6.987 indivíduos, distribuídos em 35 famílias botânicas, 82 gêneros e 153 espécies. Do total de indivíduos, aproximadamente $41 \%$ são dispersos por animais, $37 \%$ por mecanismos próprios e $21 \%$ pela ação do vento. Com relação às espécies, 47\% possuem dispersão zoocórica, 23\% autocórica e 14\% anemocórica. Os padrões de dispersão de sementes variam em conformidade aos níveis de altitudes, com tendência de regiões mais elevadas apresentarem maior representatividade de dispersores bióticos e as mais baixas, abióticos.

Palavras-chave: Floresta seca. Caatinga. Autoecologia.
\end{abstract}

\begin{abstract}
The objective of this study was to assess the patterns of seed dispersal syndromes of woody plants from nine forest fragments distributed at different altitude levels on the Araripe plateau, in Pernambuco, Brazil. For data collection, we divided the altitudes within the region into three categories: lower level (altitudes $\leq 600 \mathrm{~m}$ ); intermediate level $(600<$ altitudes $<750 \mathrm{~m})$; and higher level (altitudes $\geq 750 \mathrm{~m})$. We registered nine fragments, three per altitude level. In each of them, we distributed 20 rectangular sampling units with $250 \mathrm{~m}^{2}$, totaling a sampling area of 4.5 ha. We quantified, collected, and identified woody plants with a diameter at breast height higher than or equal to $0.1 \mathrm{~m}$ (DBH $1.30 \mathrm{~m} \geq 0.10 \mathrm{~m}$ ). We characterized the dispersal syndrome according to the characteristics of the fruits and seeds and based on a literature review. In the whole region, we sampled 6,987 individuals, distributed in 35 families, 82 genera, and 153 species. Approximately $41 \%$ of all individuals are dispersed by animals, $37 \%$ by the plant's own mechanisms, and $21 \%$ by the wind. In terms of dispersal, $47 \%$ of species were classified as zoochorous, $23 \%$ as autochorous, and $14 \%$ as anemochorous. Seed dispersal patterns vary according to altitude levels, with higher regions tending to present greater representativeness of biotic dispersers and lower ones, abiotic.

Keywords: Dry forest. Caatinga. Autoecology.
\end{abstract}

\section{INTRODUCTION}

The Araripe region has endured one of the greatest environmental impacts in recent years, since its native vegetation has been destroyed and replaced by anthropogenic landscapes, leading to the process of desertification in many areas. This issue is aggravated by the fact that these areas are mountainous regions subject to orographic effects, responsible for the formation of highly diverse micro-habitats.

The topography is a geographical variable that causes environmental heterogeneity, mainly due to its influence on the distribution and intensity of rainfall, with a variation in the precipitation levels caused by the orographic effect from the topographic obstacles. This variable is also responsible for the formation of a complex composition of soils, with different grain sizes and fertility. These environmental variations result in the formation of different fauna and flora micro-habitats, with compositions that vary according to specific

FLORESTA, Curitiba, PR, v. 50, n. 4, p. 1751 - 1760, out/dez 2020.

Santos, W. B. et.al.

ISSN eletrônico 1982-4688

DOI: $10.5380 /$ rf.v50 i4. 64832 
ecological niches (ARRUDA et al., 2015; HIGUCHI et al., 2016; NEVES et al., 2016; SANTOS; NASCIMENTO, 2017).

The understanding of biological processes in regions with different altitudes is important for the management and conservation of biodiversity, because the interaction of environmental variables with fauna and flora result in different spatial patterns of biota, resulting in areas with varied phytophysionomies, which are called biogeographic islands (DALMASO et al., 2013; AMJAD et al., 2016; SANTANA et al., 2016; SILVA et al., 2017).

The composition and the dynamics of the flora of forest communities are directly related not only to seed dispersal processes but also to levels of inter-and intraspecific competition and to available environmental resources. The recruitment and establishment of individuals in a forest depend on numerous ecological filters, and the most important of them is seed dispersal, which consists of the process of spreading diaspores that are driven away from the mother plant, reducing intraspecific competition. The source of diaspores and their dispersal are essential conditions for successful forest regeneration, with the spread subject to the fecundity of the adult tree and on the presence of dispersal vectors (HOWE; MIRITI, 2004; CHAZDON, 2016; KROSCHEL et al., 2016).

In tropical forests, there are many biotic and abiotic vectors responsible for seed dispersal, mainly animals, wind, and gravity. Since birds can travel long distances, they are very effective dispersers; while ants, bats, and other mammals also play important roles for shorter routes (SUMMERBELL, 1991; BUTLER et al., 2007; SILVA; RODAL, 2009; SILVA et al., 2013).

Studies that provide more detailed information on the seed dispersal in native forests under different altitudes can be extremely useful for ecological projects aimed at the conservation and restoration of biodiversity, in addition to indicating species that have greater chances at a successful germination. The many researchers from several fields who seek a better understanding of the seed dispersal dynamics within diverse biomes and phytophysionomies are proof of this importance (SILVA et al., 2015; GOMES; QUIRINO, 2016; KROSCHEL et al., 2016; COSTA et al., 2017; RAMÓN et al., 2018; THIELE et al., 2018)

Therefore, this study aimed to assess the patterns of seed dispersal syndromes of woody plants from nine forest fragments distributed within different altitudes of the Araripe plateau in Pernambuco, Brazil.

\section{MATERIALS AND METHODS}

This study was developed in nine forest fragments, distributed at different altitudes in the micro-region of Araripina, in the Araripe region, in west Pernambuco, Brazil (Figure 1).

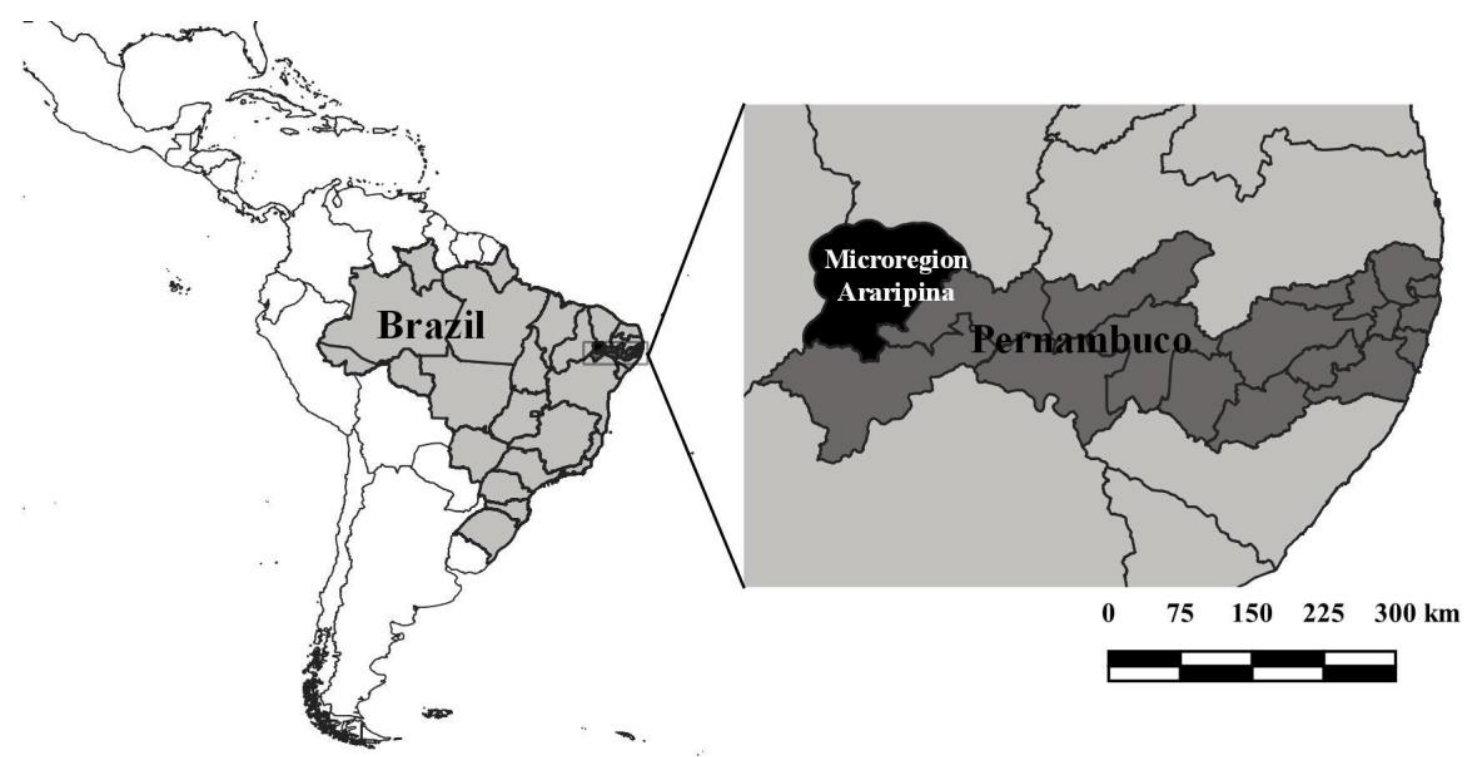

Figure 1. Location of the study areas in the microregion of Araripina, in the Araripe region, west Pernambuco, Brazil.

Figura 1. Mapa de localização das áreas de estudos na microrregião de Araripina, região do Araripe, extremo oeste de Pernambuco, Brasil. 
The altitudes in the region vary between 400 and $1000 \mathrm{~m}$. According to the Köppen classification, the climate of the Cerrado region is characterized as BSh', hot semiarid with low latitude and low altitude terrain, and low or irregular rainfall that increases at higher altitudes. The Technical Manual of the Brazilian Vegetation classifies this formation as Steppic Savannah; however, this umbrella term is divided into the following phytophysionomic categories: Shrubby Caatinga, Shrubby-Arboreal Caatinga, Arboreal Caatinga, Cerrado, Cerradão, Rainforest, Secondary Forest, Carrasco, Cerradão-carrasco and Dry Forest (BRASIL; MINISTÉRIO DO MEIO AMBIENTE, 2007; IBGE, 2012; ALVARES et al., 2013).

The sample consisted of 180 distributed rectangular sampling units, with dimensions of $250 \mathrm{~m} 2 \mathrm{each}$ throughout a sampling area of 4.5 ha. The region was divided into three levels of altitudes: lower level (altitudes $\leq 600 \mathrm{~m})$; intermediate level $(600<$ altitude $<750 \mathrm{~m})$; and higher level (altitudes $\geq 750 \mathrm{~m}$ ). At each altitude level, 60 plots were allocated, distributed in three distinct forest fragments, 20 in each, with a sample area of 1.5 ha per stratum (Table 1).

Table 1. Characterization of nine fragments of native forests at different levels of altitudes within the semiarid region in the Araripe plateau, Pernambuco, Brazil.

Tabela 1. Caracterização de nove fragmentos de florestas nativas em diferentes níveis de altitudes de região semiárida na Serra do Araripe, Pernambuco, Brasil.

\begin{tabular}{ccccl}
\hline Fragments & Altitude levels & Altitudes & Geographical Coordinates & Forest Typology \\
\hline F1 & Lower level & $540 \mathrm{~m}$ & $7^{\circ} 46^{\prime} 58.28^{\prime \prime} ; 40^{\circ} 27^{\prime} 13.73 " \mathrm{~W}$ & Shrub-Arboreal Caatinga \\
F2 & Lower level & $605 \mathrm{~m}$ & $7^{\circ} 36^{\prime} 19.62^{\prime \prime} \mathrm{S} ; 40^{\circ} 28^{\prime} 53.67^{\prime \prime} \mathrm{W}$ & Arboreal Caatinga \\
F3 & Lower level & $546 \mathrm{~m}$ & $7^{\circ} 42^{\prime} 02.67^{\prime \prime S} ; 40^{\circ} 23^{\prime} 15.11^{\prime \prime} \mathrm{W}$ & Shrub-Arboreal Caatinga \\
F4 & Intermediary levels & $681 \mathrm{~m}$ & $7^{\circ} 36^{\prime} 19.69 " \mathrm{~S} ; 40^{\circ} 32^{\prime} 15.60^{\prime \prime} \mathrm{W}$ & Caatinga-Cerrado Transition \\
F5 & Intermediary levels & $664 \mathrm{~m}$ & $7^{\circ} 31^{\prime} 09.16^{\prime \prime S} ; 40^{\circ} 30^{\prime} 54.01^{\prime \prime} \mathrm{W}$ & Caatinga-Cerrado Transition \\
F6 & Intermediary levels & $715 \mathrm{~m}$ & $7^{\circ} 33^{\prime} 23.78^{\prime \prime S} ; 40^{\circ} 33^{\prime} 15.75^{\prime \prime} \mathrm{W}$ & Caatinga-Cerrado Transition \\
F7 & Higher levels & $847 \mathrm{~m}$ & $7^{\circ} 25^{\prime} 36.28 " \mathrm{~S} ; 40^{\circ} 25^{\prime} 44.71^{\prime \prime} \mathrm{W}$ & Carrasco \\
F8 & Higher levels & $801 \mathrm{~m}$ & $7^{\circ} 32^{\prime} 54.81 " \mathrm{~S} ; 40^{\circ} 18^{\prime} 15.98^{\prime \prime} \mathrm{W}$ & Transition Carrasco-Rainforest \\
F9 & Higher levels & $951 \mathrm{~m}$ & $7^{\circ} 28^{\prime} 14.16 " \mathrm{~S} ; 39^{\circ} 39^{\prime} 38.15^{\prime \prime} \mathrm{W}$ & Rainforest \\
\hline
\end{tabular}

The classification and characterization of forest fragments were carried out through field observations and adaptations to the Forest diagnosis of the Araripe region by the Ministry of the Environment (BRASIL; MMA 2007). Fragments were divided as follows: F1, F2 and F3 are fragments from lower altitude levels $(\leq 600$ $\mathrm{m})$. F1 is composed of medium-sized deciduous vegetation that is over 100 years old. F2 is of tall deciduous vegetation that is over 100 years old. F3 has medium-sized deciduous vegetation that has undergone clearcutting and is about 25 years old. F4, F5, and F6 are fragments from intermediate altitude levels ( $>600$ and $<750 \mathrm{~m}$ ), all with medium-sized deciduous vegetation and over 100 years old. F7, F8, and F9 belong to higher altitude levels $(\geq 750 \mathrm{~m}) . \mathrm{F} 7$ is represented by short deciduous vegetation with the presence of many lianas. F8 has mediumsized semideciduous vegetation. F9 is composed of tall perennial vegetation near water reservoirs. All of the latter areas are more than 100 years old, found in flat terrain and sandy soils.

We collected and screened the botanical material of all woody plants in the plots, with a diameter at breast height higher than or equal to $0.1 \mathrm{~m}$ (DBH $1.30 \mathrm{~m}$ above ground level $\geq 0.10 \mathrm{~m}$ ). Experts helped to identify the species by comparing them with exsiccates stored in the Herbarium Sergio Tavares of the Department of Forest Science of the Federal Rural University of Pernambuco (HST/UFRPE). Exsiccates of the species found in the plots were added to the herbarium.

We determined the dispersal syndromes according to the Pijl (1982) classification: anemochorous (ANE) plants have structures that facilitate dispersal by wind, such as wings, feathers or hair; autochorous (AUT) plants have mechanisms for the release of diaspores, such as the release of tension and explosive pods; and zoochorous (ZOO) plants have features that support dispersal by animals, such as fleshy diasporas, like berries and drupes, or fleshy appendages on seeds.

In order to identify the dispersal method of each species, we collected fertile botanical materials to inspect the morphological characteristics of the propagules and to consult the classifications already available in the literature.

The assessment was performed for each altitude level and forest fragment, considering both woody species and individuals.

FLORESTA, Curitiba, PR, v. 50, n. 4, p. 1751 - 1760, out/dez 2020.

Santos, W. B. et.al.

ISSN eletrônico 1982-4688

DOI: $10.5380 /$ rf.v50 i4. 64832 


\section{RESULTS}

We sampled a total of 6,987 individuals throughout the region, divided into 35 families, 82 genera, and 153 species. Regarding the dispersal of species, $47 \%$ presented zoochory, $23 \%$ autochory, $14 \%$ anemochory and $16 \%$ were not categorized. As for individuals, $41 \%$ are dispersed by animals, $37 \%$ by own mechanisms, $21 \%$ by wind, and $2 \%$ had unidentified dispersing agents.

The three levels of altitudes presented a higher percentage of species dispersed by animals, while the lowest was wind. Autochory was prevalent in lower and intermediate levels (altitudes <750 m) while zoochory was more prevalent in higher levels $(\geq 750 \mathrm{~m})$.

Regarding the number of species and individuals, the lower and intermediate levels presented similar patterns, having similar percentage values regarding the syndromes, while zoochory was less common at altitudes $<600 \mathrm{~m}$. Higher altitude levels presented a different pattern from the others, with a divergent percentage of species and individuals with zoochorous dispersal, as well as poor representativeness of anemochory and autochory (Figure 2).

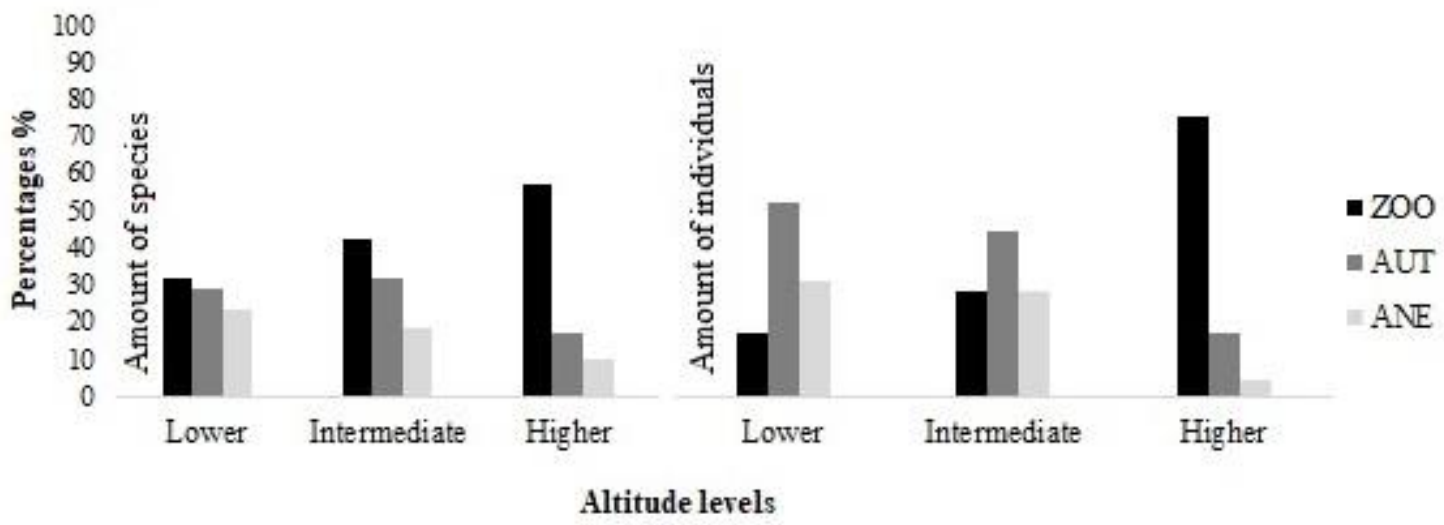

Figure 2. Dispersal syndromes of native woody species and individuals at three levels of altitudes (lower: altitude $\leq 600 \mathrm{~m}$; intermediate: $600<$ altitude $<750 \mathrm{~m}$; and higher: altitude $\geq 750 \mathrm{~m}$ ) in the semiarid region in the Araripe plateau, Pernambuco, Brazil.

Figura 2. Síndrome de dispersão de espécies e indivíduos lenhosos nativos em três níveis de altitudes (inferior: altitude $\leq 600 \mathrm{~m}$; intermediário: $600<$ altitude $<750 \mathrm{~m}$; e superior: altitude $\geq 750 \mathrm{~m}$ ) em região semiárida na Serra do Araripe, Pernambuco, Brasil.

At altitudes up to $750 \mathrm{~m}$ (lower and intermediate levels), the fragments showed no significant differences in the distribution of species by syndrome, being higher in the following descending order: zoochory, autochory, and anemochory. In the lower level of altitude, 32\% of the species were zoochorous, $29 \%$ autochorous and 23\% anemochorous; as for the intermediate level, the rates were 42, 32 and 18\%, respectively. The distribution pattern changed when taking the abundance of individuals into account, with the two levels of altitudes showing a higher percentage of autochory (52\% for lower levels and $44 \%$ for intermediate levels) At altitudes up to $600 \mathrm{~m}$, anemochory was more prevalent, (31\%); at intermediate levels, similar values were found for anemochory and zoochory $(28 \%)$.

At altitudes equal to or higher than $750 \mathrm{~m}$, there was a greater discrepancy in the distribution of species and individuals by syndrome, with high percentage values of zoochory $(57 \%$ and $75 \%)$ and a decrease in anemochory $(10 \%$ and $4 \%)$ when compared with the other levels.

According to the patterns of distribution of species and individuals by syndrome, with the increase in altitude, zoochorous dispersal also tended to increase while anemochorous dispersal decreased.

The variation in the distribution patterns of species and individuals by syndrome can also be observed between forest fragments at the same altitude level.

At altitudes of up to $600 \mathrm{~m}, \mathrm{~F} 1$ presented a higher number of autochorous species (43\%), whereas F2 and F3 had more zoochorous species (43\% and 44\%). Considering the abundance of individuals, F1 and F3 had a higher percentage of autochory (71\% and $68 \%)$, followed by anemochory $(16 \%$ and $19 \%)$ and zoochory $(12 \%$ and $13 \%$ ), whereas F2 had a more balanced distribution between anemochory (43\%) and autochory (36\%) (Figure 3).

FLORESTA, Curitiba, PR, v. 50, n. 4, p. 1751 - 1760, out/dez 2020.

Santos, W. B. et.al.

ISSN eletrônico 1982-4688

DOI: 10.5380/rf.v50 i4. 64832 


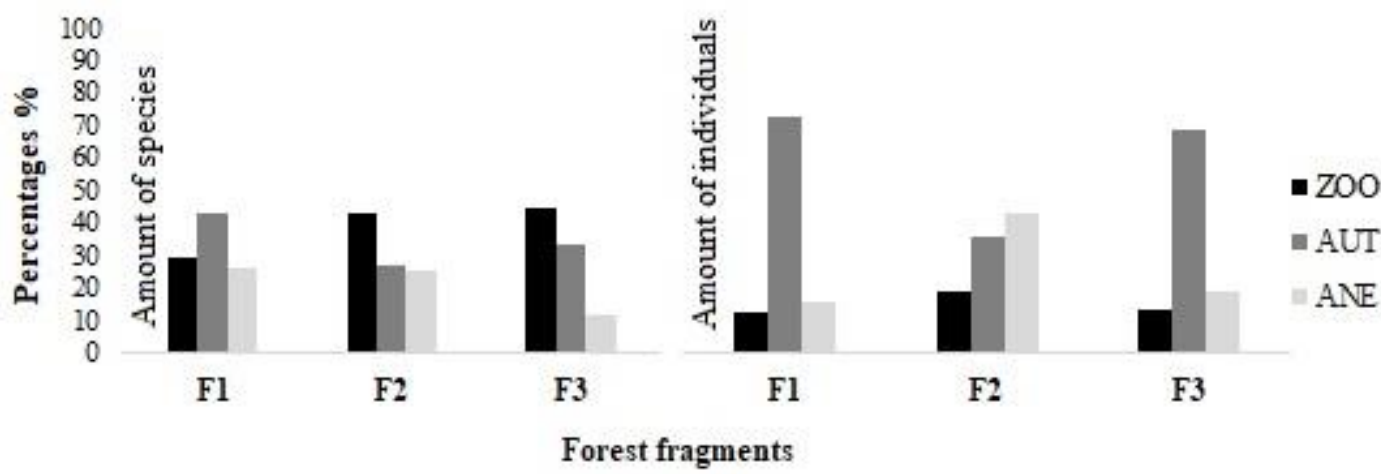

Figure 3. Dispersal syndromes of native woody species and individuals from three forest fragments with altitudes up to $600 \mathrm{~m}$, in a semiarid region in the Araripe plateau, Pernambuco, Brazil.

Figura 3. Síndromes de dispersão de espécies e indivíduos lenhosos nativos de três fragmentos florestais com altitudes de até 600 m, em região semiárida na Serra do Araripe, Pernambuco, Brasil.

In F1, we found: 14 species with autochorous dispersal, distributed into two families, Fabaceae (eight species) and Euphorbiaceae (six species); nine anemochorous, into five families; and 10 zoochorous, into nine families.

F2 presented: 14 autochorous species, distributed into three families, Fabaceae (three species), Euphorbiaceae (six species) and Malvaceae (one species); 13 anemochorous, into seven families (Anacardiaceae, Apocynaceae, Bignoniaceae, Combretaceae, Fabaceae, Malvaceae, Meliaceae and Rubiaceae); and 22 zoochorous, into 16 families. Fabaceae was the only family presenting species of the three dispersal types.

In F3, nine autochorous species were found, distributed into two families, Fabaceae (six species) and Euphorbiaceae (three species); three anemochorous, into two families, Anacardiaceae and Combretaceae; and 12 zoochorous, into 11 families.

The predominance of individuals with autochorous dispersal in F1 and F3 is mainly due to the abundance of two species, Croton blanchetianus Baill. (Euphorbiaceae) and Poincianella gardneriana (Benth.) L.P. Queiroz (Fabaceae), representing together $53 \%$ of all individuals and $75 \%$ of the autochorous in F1, and regarding $\mathrm{F} 3,57 \%$ and $84 \%$, respectively.

On the other hand, F2 had no evident predominance, presenting a good representativeness of anemochory and autochory. The wind-dispersed species with the biggest number of individuals were the following, in descending order: Coutarea alba Griseb., Parapiptadenia zehntneri (Harms.) M. P. Lima \& H. C. Lima, Aspidosperma cuspa (Kunth) S. F. Blake ex Pittier and Amburana cearensis (Allemão) A. C. Sm., representing $32 \%$ of all the individuals in the community and $75 \%$ of the anemochorous. Regarding those dispersed by their own mechanisms, in addition to Croton blanchetianus and Poincianella gardneriana that stand out in F1 and F3, Croton sp. also showed a high population density, representing $27 \%$ of the total and $76 \%$ of the autochorous in this fragment.

This variation between fragments of the lower altitude level may be associated with the difference in phytophysiognomy, since F1 and F3 belong to the Shrubby-Arboreal Caatinga phytophysiognomy, which has sparse trees, with little esterification in the succession and understory areas, facilitating the dispersal by gravity. On the other hand, F2 has an Arboreal Caatinga phytophysiognomy, presenting more defined successional strata, with understory and superior stratum, increasing competition between individuals and benefiting those who are able to disseminate to more distant places, in this case, the wind.

The three fragments showed patterns of distribution of species by similar syndromes in altitudes of 600 to $750 \mathrm{~m}$. There was a greater variation in the analysis of the individuals, with $\mathrm{F} 4$ showing a higher percentage of anemochorous and autochorous (37\% and 35\%), while F5 presented $36 \%$ of each zoochorous and autochorous and F6, 67\% autochorous (Figure 4). 


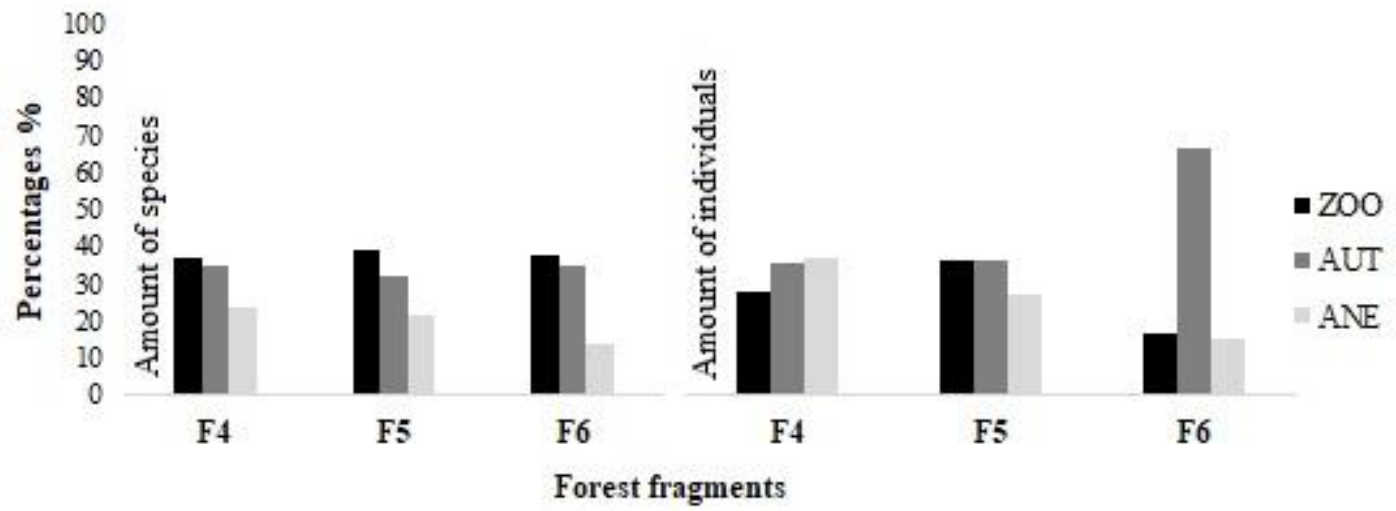

Figure 4. Dispersal syndromes native woody species and individuals from three forest fragments with altitudes from 600 to $750 \mathrm{~m}$, in a semiarid region in the Araripe plateau, Pernambuco, Brazil.

Figura 4. Síndromes de dispersão de espécies e indivíduos lenhosos nativos de três fragmentos florestais com altitudes de 600 a 750 m, em região semiárida na Serra do Araripe, Pernambuco, Brasil.

In F4, we observed: 18 zoochorous species, distributed in 10 families; 15 autochorous, in three families (Fabaceae, Euphorbiaceae and Malvaceae); and 10 anemochorous, in six families (Anacardiaceae, Apocynaceae, Bignoniaceae, Combretaceae, Fabaceae and Malvaceae). In this fragment, there was a balance in the distribution of individuals by syndrome, especially the species: Combretum glaucocarpum Mart. and Dalbergia frutescens (Vell.) Britton, representing $81 \%$ of the anemochorous individuals; Croton blanchetianus, representing $71 \%$ of autochorous; and Myrcia guianensis (Aubl.) DC., representing 40\% of those dispersed by animals.

In F5, we observed: 12 zoochorous species, grouped into seven families (Annonaceae, Boraginaceae, Capparaceae, Fabaceae, Myrtaceae, Nyctaginaceae and Rutaceae); nine autochorous, into two families, Fabaceae and Euphorbiaceae; and six anemochorous, into four families, three in Bignoniaceae and one in Anacardiaceae, Combretaceae and Fabaceae.

This fragment also showed balance in the distribution of individuals by syndrome, showing greater abundance of: Cynophalla flexuosa (L.) J. Presl. (Capparaceae) and Swartzia psilonema Harms (Fabaceae), representing together, $78 \%$ of the density of zoochorous individuals; Senegalia polyphylla (DC.) Britton \& Rose (Fabaceae) and Piptadenia viridiflora (Kunth) Benth. (Fabaceae), representing $78 \%$ of autochorous individuals; and, Combretum glaucocarpum (Combretaceae) and Schinopsis brasiliensis Engl. (Anacardiaceae), representing $95 \%$ of anemochorous individuals.

In F6, we observed: 12 zoochorous species grouped into eight families (Annonaceae, Capparaceae, Fabaceae, Malpighiaceae, Meliaceae, Myrtaceae, Nyctaginaceae and Rutaceae); 10 autochorous, into three families (Fabaceae, Euphorbiaceae and Rhamnaceae); and four anemochorous, into three families (Apocynaceae, Fabaceae and Combretaceae).

In this fragment, there was a greater divergence in the distribution of individuals among syndromes, with approximately $67 \%$ of all individuals dispersed by autochory, specially the following species: Croton limae A.P.S. Gomes, M. F. Sales \& P. E. Berry, Pityrocarpa moniliformis (Benth.) Luckow \& R. W. Jobson, Bauhinia acuruana Moric., Senegalia langsdorffii (Benth.) Seigler \& Ebinger and Mimosa sp.2, representing about $61 \%$ of the total and $92 \%$ of the autochorous.

In the higher altitude fragments, the distribution of species and individuals by dispersal syndromes followed the same pattern, with a higher percentage of zoochory, followed by autochory and anemochory (Figure 5). 


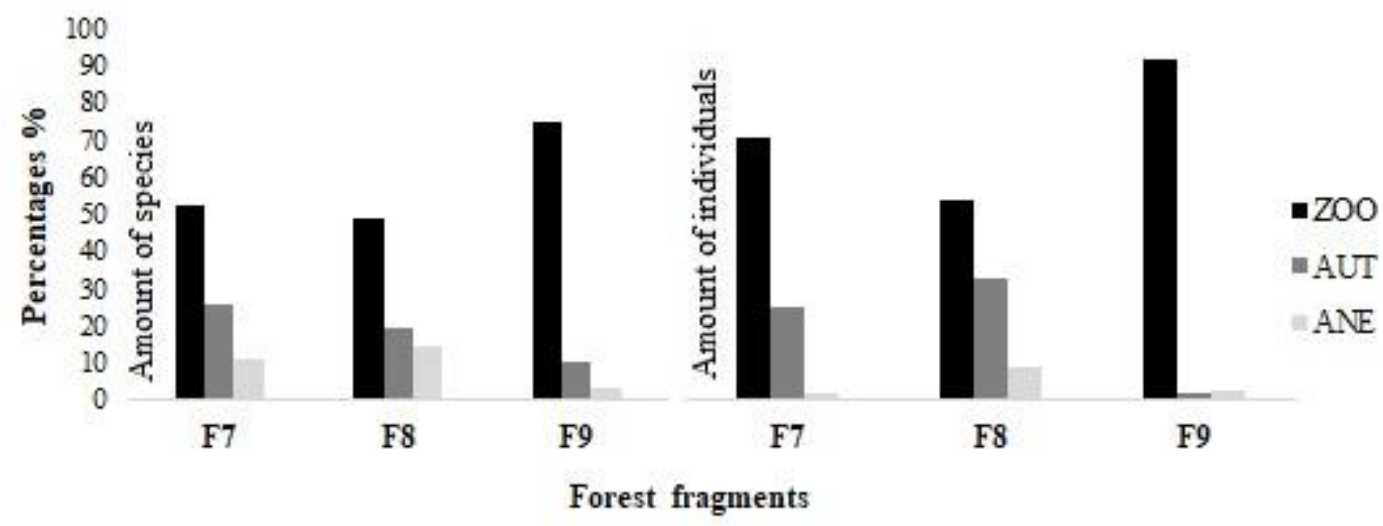

Figure 5. Dispersal syndromes of species and native woody individuals from three forest fragments with altitudes equal to or greater than $750 \mathrm{~m}$, in a semiarid region in the Araripe plateau, Pernambuco, Brazil.

Figura 5. Síndromes de dispersão de espécies e indivíduos lenhosos nativos de três fragmentos florestais com altitudes iguais ou superiores a 750 m, em região semiárida na Serra do Araripe, Pernambuco, Brasil.

In F7, we observed: 14 zoochorous species, distributed into eight families (Annonaceae, Erythroxylaceae, Fabaceae, Malpiguiaceae, Meliaceae, Myrtaceae, Nyctaginaceae and Rutaceae); seven autochorous, into three families (Fabaceae, Euphorbiaceae and Rhamnaceae); and three anemochorous, into three families (Apocynaceae, Bignoniaceae and Combretaceae).

In this fragment, we observed: $71 \%$ of individuals with zoochorous dispersal, of which about $60 \%$ were represented by the species Guapira opposita (Vell.) Reitz and Metrodorea mollis Taub.; 25\% dispersed by autochory, of which $73 \%$ belong to Croton limae; and only $2 \%$ by anemochory, by species, Aspidosperma pyrifolium Mart., Jacaranda jasminoides (Thunb.) Sandwith and Combretum glaucocarpum.

The fragment F8 presented: 20 zoochorous species, distributed into 10 families (Annonaceae, Erythroxylaceae, Fabaceae, Malpighiaceae, Meliaceae, Myrtaceae, Nyctaginaceae, Rutaceae, Salicaceae and Sapindaceae); eight autochorous, into two families (six in Fabaceae and two in Euphorbiaceae); and six anemochorous, into four families (three Bignoniaceae and one in Anacardiaceae, Combretaceae and Fabaceae).

This fragment showed: $54 \%$ of the individuals dispersed by animals, especially the species Erythroxylum caatingae Plowman, Metrodorea mollis and Pilocarpus spicatus subsp. aracatensis Kaastra; 32\% for autochorous, with emphasis on Croton limae; and only $9 \%$ for anemochory, specially Combretum glaucocarpum.

F9 presented $75 \%$ of species dispersed by zoochory, $10 \%$ by autochory and only $3 \%$ by anemochory. We registered: 30 zoochorous species, grouped into 20 families; four autochorous, into three families (Euphorbiaceae, Fabaceae and Rhamnaceae); and only the Roupala montana Aubl. (Proteaceae) with anemochorous dispersal. This fragment presented $92 \%$ of the individuals dispersed by animals, with emphasis on population density, Ocotea nitida (Meisn.) Rohwer (Lauraceae) and Matayba guianensis Aubl. (Sapindaceae). Only $2 \%$ of individuals had autochorous and anemochorous dispersal.

\section{DISCUSSION}

The analysis of the three levels demonstrates a tendency for an increase in the zoochorous dispersal and a decrease in the anemochorous and autochorous dispersal according to the elevation of the altitude. Several studies in the literature demonstrate a greater representativeness of abiotic dispersal in Caatinga areas and of biotic at higher altitudes. The pattern of dispersal syndromes may be associated with the degree of rainfall, since in Caatinga areas, which have severe droughts for the most part of the year, there is a predominance of abiotic dispersers (autochory and anemochory). Conversely, at higher altitudes, the increase in rainfall brings a greater diversity of biotic dispersers, mainly due to the offer of more fleshy and attractive fruits for animals (COSTA et al., 2004; BUTLER et al., 2007; SILVA; RODAL, 2009; SILVA et al., 2013).

The variation between fragments at the same altitude level may be associated with the precipitation levels and differences in phytophysiognomic. F1 and F3, with a Shrubby-Arboreal Caatinga phytophysiognomy, present a higher percentage of individuals with autochorous dispersal in areas with an altitude up to $600 \mathrm{~m}$. On the other hand, F2 has more representativeness of anemochorous species, having an Arboreal Caatinga

FLORESTA, Curitiba, PR, v. 50, n. 4, p. 1751 - 1760, out/dez 2020.

Santos, W. B. et.al.

ISSN eletrônico 1982-4688

DOI: $10.5380 /$ rf.v50 i4. 64832 
phytophysiognomy. Anemochorous species are generally emergent, since they need more intense air currents for the propagation of propagules (YAMAMOTO, KINOSHITA; MARTINS, 2007; SILVA; RODAL, 2009).

At altitudes of 600 to $750 \mathrm{~m}$ (intermediate level of altitude), there is a greater similarity in the pattern of species distribution by dispersal syndromes; however, there are limitations or environmental variations that cause changes in the patterns of individuals' abundance. A good example is F6, which has a high spread of individuals by autochory that may be a consequence of the greater semiaridity of the area, since despite being the one with the highest altitude $(715 \mathrm{~m})$, it is the most inclined, with shallow soils and rocky outcrops.

At the lower and intermediate levels of altitudes, despite the high number of zoochorous species, there is greater dissemination of individuals by abiotic agents. This may reflect the lack or less abundance and diversity of dispersers (fauna), since these areas have a drier climate and less rainfall, causing restrictions and natural selection of animals that are more resistant to prolonged droughts.

In spite of the predominance of the zoochorous dispersal, in the comparison of the three fragments of the higher level of altitude, a clear variation was observed in the distribution patterns of species and individuals according to the intensity of the semiaridity. F7 and F8 areas, which are drier, showed greater similarities; however, F8, which is located in a more humid region having greater rainfall intensities, diverges with a discrepant number of species and individuals dispersed by animals and very little representativeness of the anemochorous.

Studies on tropical forests, that find the highest percentage of species with zoochorous dispersal, are frequent. Silva et al. (2015), in a study carried out within the limits of the Environmental Protection Area of the Araripe plateau, as well as Gomes and Quirino (2016), in a study carried out in the Caatinga area in Cariri (Paraíba), also observed greater representativeness of species dispersed by animals.

Of the 13 species present in the three altitude levels, six are dispersed by animals (Allophylus quercifolius Radlk., Annona leptopetala (R.E. Fr.) H. Rainer, Chloroleucon foliolosum (Benth.) G. P. Lewis, Guapira opposita, Myrcia sp. e Zanthoxylum gardneri Engl.), four by wind (Aspidosperma pyrifolium, Combretum glaucocarpum, Handroanthus impetiginosus (Mart. ex DC.) Mattos e Schinopsis brasiliensis) and three by the plants' own mechanisms (Bauhinia subclavata Benth., Piptadenia viridiflora e Senegalia polyphylla (DC.) Britton \& Rose). Zoochorous dispersals most likely have animals that travel long distances, such as birds, as the main dispersers.

We observed that, in the Araripe region, abiotic syndromes have reached greater distances in the spread of species. $41 \%$ of anemochorous are present at at least two levels of altitudes, $64 \%$ in more than one fragment and $36 \%$ in isolation, which means in only one of the areas. Regarding autochorous, $46 \%$ are present in more than one altitude level, $66 \%$ in more than one fragment and 34\% in isolation. Regarding those dispersed by animals, $24 \%$ are present in more than one stratum of altitude, $37 \%$ in at least two fragments and $63 \%$ in isolation, half of which are exclusive to area F9. The levels of semiaridity in association with the varied orographic effects of this region has probably incited the formation of a diversity of microclimates, which act as true islands, limiting the existence and the movement of certain groups of animals in isolated ecological niches.

\section{CONCLUSION}

- The patterns of dispersal syndromes vary according to altitude levels, with a tendency for higher percentage of species and individuals with biotic dispersal in higher regions, while the lower regions present abiotic dispersals.

- There is variation in the dispersal patterns, although there is a higher percentage of species dispersed by animals in the fragments. The areas of the lower and intermediate levels of altitude, presented smaller variations between the syndromes, without divergence in the percentage values, while the areas of the higher level presented a predominance of zoochorous species and a reduction of anemochorous species.

- The variation in the patterns is more evident when considering only the abundance of individuals by dispersal syndromes, with the Caatingas areas (altitudes $\leq 600 \mathrm{~m}$ ) presenting predominance of abiotic dispersal (autochory and anemochory), and the fragments with altitudes from 600 to $750 \mathrm{~m}$ functioning as an ecotone of the lower and higher levels, thus representing both biotic and abiotic dispersal. In areas with altitudes $\geq 750 \mathrm{~m}$, animals are the main dispersers.

\section{ACKNOWLEDGMENTS}

This study had the financial support of the Coordination for the Improvement of Higher Education Personnel - Brazil (CAPES), with the financing code 001, as well as the financial support from the State of Pernambuco Foundation for Science and Technology Support (FACEPE).

FLORESTA, Curitiba, PR, v. 50, n. 4, p. 1751 - 1760, out/dez 2020.

Santos, W. B. et.al.

ISSN eletrônico 1982-4688

DOI: $10.5380 /$ rf.v50 i4. 64832 


\section{REFERENCES}

ALVARES, C. A.; STAPE, J. L.; SENTELHAS, P. C.; GONÇALVES, J. L. M.; SPAROVEK, G. Köppen's climate classification map for Brazil. Meteorologische Zeitschrift, Stuttgard, v. 22, n. 6, p. 711-728, 2013.

AMJAD, M. S.; ARSHAD, M.; SADAF, H. M.; DURR-E-SHAHWAR; AKRIM, F.; ARSHAD, A. Floristic composition, biological spectrum and conservation status of the vegetation in Nikyal valley, Azad Jammu and Kashmir. Asian Pacific Journal of Tropical Disease, [s.I], v. 6, n, 1, p. 63-69, 2016.

ARRUDA, D. M.; SCHAEFER, C. E. G. R.; CORRÊA, G. R.; RODRIGUES, P. M. S.; DUQUE-BRASIL, R. FERREIRA JUNIOR, W. G.; OLIVEIRA-FILHO, A. T. Landforms and soil attributes determine the vegetation structure in the Brazilian semiarid. Folia Geobotanica, Praha, v. 50, p. 175-184, 2015.

BRASIL. Ministério do Meio Ambiente. Potencial Florestal da Região do Araripe. In: Região do Araripe, Pernambuco, Diagnóstico Florestal. Brasília, 2007. p. 15-36.

BUTLER, D. W.; GREEN, R. J.; LAMB, D.; MCDONALD, W. J. F.; FORSTER, P. I. Biogeography of seeddispersal syndromes, life-forms and seed sizes among woody rain-forest plants in Australia's subtropics. Journal of Biogeography, Oxford, v. 34, n. 10, p. 1736-1750, 2007.

CHAZDON, R. L. Renascimento de Florestas: Regeneração na era do desmatamento. Editora: Oficina de Textos 2016. 432p

COSTA, M. B.; MENEZES, L. F.; NASCIMENTO, M. T. Post-fire regeneration in seasonally dry tropical forest fragments in southeastern Brazil. Anais da Academia Brasileira de Ciências, [s.I], v. 89, n.4, p. 2687-2695, 2017.

DALMASO, C. A.; INOUE, M. T.; OLIVEIRA FILHO, P. C.; MARCELINO, V. R. Padrões espaciais na regeneração de Ocotea odorifera na floresta nacional de Irati, PR. Floresta, Curitiba, v. 43, n. 2, p. 301-312, 2013.

GOMES, V. G. N.; QUIRINO, Z. G. M. Síndromes de dispersão de espécies vegetais no Cariri Paraibano. Revista Brasileira de Geografia Física, Recife, v. 09, n. 4, p. 1157-1167, 2016.

HIGUCHI, P.; SILVA, A. C.; FERREIRA, T. S.; SOUZA, S. T.; GOMES, J. P.; SILVA, K. M.; SANTOS, K. F.; BERNDT, E. J.; SOUZA JUNIOR, J. O.; GOIS, D. T.; WEIDUSCHAT, F. Florística e estrutura do componente arbóreo e relação com variáveis ambientais em um remanescente florestal em Campos Novos - SC. Ciência Florestal, Santa Maria, v. 26, n. 1, p. 35-46, 2016.

HOWE, H. F.; MIRITI, M.N. When seed dispersal matters. BioScience, Uberlândia, v.54, p.651-660, 2004.

INSTITUTO BRASILEIRO DE GEOGRAFIA E ESTATÍ́STICA (IBGE). Manual técnico da vegetação brasileira. 2. ed. ver. e ampl. Rio de Janeiro, 2012, 271p.

KROSCHEL, W. A.; KING, S. L.; KEIM, R. F. Tree Regeneration by Seed in Bottomland Hardwood Forests: A Review. Southeastern Naturalist, Steuben, v. 15, n. 9, p. 42-60, 2016.

NEVES, S. P. S.; FUNCH, R.; CONCEIÇÃO, A. A.; MIRANDA, L. A. P.; FUNCH, L. S. What are the most important factors determining different vegetation types in the Chapada Diamantina, Brazil? Brazilian Journal of Biology, São Carlos, v. 76, n. 2, p. 315-333, 2016.

PIJL, V. D. L. Principles of dispersal in higher plants. Springer-Verlag, New York, 1982. 162p.

RAMÓN, P.; VELÁZQUEZ, E.; ESCUDERO, A.; DE LA CRUZ, M. Environmental heterogeneity blurs the signature of dispersal syndromes on spatial patterns of woody species in a moist tropical forest. PLoS ONE, San Francisco, v. 13, n. 2, p. 1-14, 2018.

SANTANA, J. A. S.; SANTANA JUNIOR, J. A. S.; BARRETO, W. S.; FERREIRA, A. T. S. Estrutura e distribuição espacial da vegetação da Caatinga na Estação Ecológica do Seridó, RN. Pesquisa Florestal Brasileira, Colombo, v. 36, n. 88, p. 355-361, 2016.

SANTOS, F. L. A.; NASCIMENTO, F. R. Dinâmica hidroclimática do Planalto da Ibiapaba e sua depressão periférica circunjacente: estudo de caso nos municípios de Tianguá e Ubajara-Noroeste do Ceará. Revista Ra'e Ga, Curitiba, v. 39, p. 57-75, 2017.

FLORESTA, Curitiba, PR, v. 50, n. 4, p. 1751 - 1760, out/dez 2020.

Santos, W. B. et.al.

ISSN eletrônico 1982-4688

DOI: $10.5380 /$ rf.v50 i4. 64832 
Silva, A. C. C.; PRATA, A. P. N.; MEllo, A. A.; SANTOS, A. C. A. S. Síndromes de dispersão de angiospermas em uma unidade de conservação na Caatinga, SE, Brasil. Hoehnea, São Paulo, v, 40, n. 4, p. 601 609,2013

SILVA, J. O.; SILVA, A. C.; HIGUCHI, P.; MAFRA, A. L.; GONÇALVES, D. A.; BUZZI JUNIOR, F.; ROSA, A. D.; CRUZ, A. P.; SOUZA, T. Floristic composition and phytogeography contextualization of the natural regeneration of an Alluvial Forest located in the "Planalto Sul Catarinense" Region, SC, Brazil. Revista Árvore, Viçosa, v. 41, n. 2, p. 1-9, 2017.

SILVA, M. A. M.; FERREIRA, W. N.; MACÊDO, M. J. F.; SILVA, M. A. P.; SOUZA, M. M. A. Composição florística e características ecológicas de um cerradão em Nova Olinda, CE. Caderno de Cultura e Ciência, Crato, v.14, n.1, 2015.

SILVA, M. C. N. A.; RODAL, M. J. N. Padrões das síndromes de dispersão de plantas em áreas com diferentes graus de pluviosidade, PE, Brasil. Acta Botânica Brasílica, Brasília, v. 23, n. 4, p. 1040-1047, 2009.

SUMMERBELL G. Regeneration of complex notophyll vine forest (humid subtropical rainforest) in eastern Australia - a review. Cunninghamia. v. 2, n. 3, p. 391-410, 1991.

THIELE, J.; SCHIRMEL, J.; BUCHHOLZ, S. Effectiveness of corridors varies among phytosociological plant groups and dispersal syndromes. PLoS ONE, San Francisco, v. 13, n. 7, p. 1-16, 2018.

YAMAMOTO, L. F.; KINOSHITA, L. S.; MARTINS, F. R. Síndromes de polinização e de dispersão em fragmentos da Floresta Estacional Semidecídua Montana, SP, Brasil. Acta botânica brasílica, Brasília, v. 21, n. 3, p. 553-573,2007. 